\title{
WestVirginiaUniversity
}

THE RESEARCH REPOSITORY @ WVU

Graduate Theses, Dissertations, and Problem Reports

2005

\section{The character within the actor: A journey through myself to find Manya}

Carrie L. Witting

West Virginia University

Follow this and additional works at: https://researchrepository.wvu.edu/etd

\section{Recommended Citation}

Witting, Carrie L., "The character within the actor: A journey through myself to find Manya" (2005). Graduate Theses, Dissertations, and Problem Reports. 3198.

https://researchrepository.wvu.edu/etd/3198

This Thesis is protected by copyright and/or related rights. It has been brought to you by the The Research Repository @ WVU with permission from the rights-holder(s). You are free to use this Thesis in any way that is permitted by the copyright and related rights legislation that applies to your use. For other uses you must obtain permission from the rights-holder(s) directly, unless additional rights are indicated by a Creative Commons license in the record and/ or on the work itself. This Thesis has been accepted for inclusion in WVU Graduate Theses, Dissertations, and Problem Reports collection by an authorized administrator of The Research Repository @ WVU. For more information, please contact researchrepository@mail.wvu.edu. 


\title{
The Character within the Actor: A Journey through Myself to Find Manya
}

Carrie L. Witting

\author{
Thesis submitted to the \\ College of Creative Arts \\ at West Virginia University \\ in partial fulfillment of the requirements \\ for the degree of \\ Master of Fine Arts \\ in \\ Acting
}

\author{
Theresa M. Davis, Chair \\ Phillip Beck \\ Jay Malarcher, Ph.D. \\ Jessica D. Morgan \\ Division of Theatre and Dance \\ Morgantown, West Virginia \\ 2005
}

Keywords: Acting, Theatre, Naturalism, Kolonists, Manya 


\begin{abstract}
The Character within the Actor: A Journey through Myself to Find Manya

\section{Carrie L. Witting}

The creation of the character Manya in Stephen Dykes' Kolonists required me to stop acting and begin living onstage. I have always perceived acting as a feat of doing or creating. I succumbed to a habit of falsely imitating reality and dwelled in the manufacturing of phony characters. Through a journey full of self discovery I find a character within the life I have already created: myself. Through the journey of my experiences in Kolonists, I am able to acknowledge these habits and personal misunderstandings, and encourage myself to stop imitating life onstage and allow myself to act as an outlet to provide my character's sense of truth.
\end{abstract}




\section{INTRODUCTION}

The creation of the character Manya in Stephen Dykes' Kolonists required me to stop acting and begin living onstage. The role forced me to break habits and encourage a new way of acting, opposite of anything I have ever done in order to find the truth in myself and in the role. Through a journey full of self discovery I find a character within the life I have already created: myself.

I have always perceived acting as a feat of doing or creating. After many years of crafting many characters, I found myself actually believing that in order to be brilliant onstage I must exaggerate how much a character is unlike me, and play-up those qualities; I must incorporate an exaggerated physical walk, a voice that sounds nothing like mine, and create a character bigger and bolder than any that would exist naturally in real life. Simply, I succumbed to a habit of falsely imitating reality and dwelled in the manufacturing of phony characters.

Through my experiences in Kolonists, I am beginning to acknowledge these habits and personal misunderstandings, and encourage myself to stop imitating life onstage but rather allow myself to act as an outlet to provide my character's sense of truth. Eric Morris states in his book No Acting Please that acting must come from one's own connection to his/her inner self, a "real personal nucleus" (Morris 2). Through the deep exploration and understanding of one's self that a character will become fully realized. Finding my own truth thus allows me to authenticate the journey of Manya and bring her from script to reality. 


\section{THE PLAY}

Kolonists is a play that follows the life of the Rusakov family over a period of two days. The action of the play unfolds within three acts. The setting is the Rusakov seaside dacha, or holiday home, near the town of Parnu, Estonia. It is 1996 and the play opens on the Rusakov sisters: Sveta, Manya, and Lenya who are reflecting upon their past experiences at the dacha when their father, Alexander, was still alive. The discussion of their belated father and of Lenya's twenty first birthday celebration propel

into a scene of somber celebratory reminiscing. Other characters join the sisters: Alexei, Sveta's husband, Kolya, a police officer and Lenya's fiancé, and Yakov, the dacha's caretaker. They revel in the festivity of Lenya's birthday and prepare to go out to honor Lenya. Many things are discussed within this scene, such as the impending visit of Andrei, the sisters' brother, and Vassily, their first cousin whom they have not seen since they were teenagers. Lenya reveals to Manya that she is unhappy in her relationship with Kolya. It also comes to light that the girl's Mother had taken many private trips to Russia to visit Vassily's father, Uncle Sergei. Everyone leaves the house, except Manya, who makes up a lie in order to stay home for the evening smoking and drinking and eventually passing out on the sofa.

As the play unfolds, Manya, the middle sister, clearly seems unsettled midst the world of the play. She distances herself from her family by speaking only when spoken to and weaseling out of conversations in order to find solace in smoking and drinking. Manya's character faces her main obstacle when Vassily, her long lost cousin, returns to visit the family. It soon becomes quite apparent that Vassily and Manya have great 
animosity towards each other resulting from their past childhood experiences which are alluded to throughout the play. Manya continues to act cautiously around the family and their recent received guests. As the final scene in the play progresses, Manya's mysteries become unveiled. Manya then is forced to confront such deeply hidden secrets as her mother's affair with her uncle and the death of her fiancé Grisha. Manya is devastated by these revelations and is left at the end of the play struggling to control herself through an emotional breakdown.

My initial thoughts about the play were that I did not like the script. Typically I prefer theatre that is silly and full of spectacle which allows the actors to ham or mug through their performance. At the same time, I was frightened that I would not be able to successfully portray Manya honestly, as I have little experience with roles that are based in naturalistic types of acting. Knowing Kolonists would pose an enormous challenge for me, habitually, I found myself uneasily anticipating my defeat.

I usually get cast as the funny, will-do-anything, has-no-shame, types of characters, such as Paulina and Dorcas in Winter's Tale, Maria in Twelfth Night, Wikewitch and Ralph in Anton in Show Business, and Wife of Bath in Canterbury Tales. Yet, this play proposed something different; it possessed characters that seemed like "real" people, not ridiculous caricatures. The roles seemed to demand a style of acting that I have purposely shied away from due to fear of sharing myself with audiences: naturalism.

I did not want the role of Manya. I was worried that the role would not pose a challenge for me. Yet, I knew this role was unlike any I had had before, the character 
seemed so real and so much like me - and there was my challenge. The role required an honest portrayal, as if the audience were watching real life unfold.

I have always had the opportunity to have to go to extreme levels to create a character. I always joked that it is not acting unless you do it with an accent. But now I realized just how much I believed that comment. I was thrilled with the opportunity to explore the various ranges of emotions that the role demanded, but I was anxious to know I would have to finally give up my way of acting and succumb to a more naturalistic way of acting in order to portray the reality of the character. 


\section{RESEARCH}

The role research played in creation of Manya was secondary to the integration of myself with Manya, yet is still remained as a basis for understanding basic everyday life for a Russian in Estonia. The play takes place near Parnu, Estonia in 1996, eight years after Estonia's declared sovereignty from Soviet rule. During these years Estonia was primarily occupied with proving their independence to Moscow by standing together as a country with a proud history, separate from its Soviet counterparts. Yet, many Russians in Estonia, some Estonian born, like the Rusakov family, grew more compassionate toward their new home. Nevertheless, Moscow severed all ties with Russian-Estonians and left them to fend for themselves.

Needless to say, many Russians and Estonians have strong opinions of their counterparts. For Russians, Estonia is a secondary, less civilized country. For Estonians, Russia is the big brooding heavy-handed dictator. In Kolonists, the Rusakov family has separated themselves from Russia both geographically and politically. They have grown to feel for their Estonian neighbors and have begun to understand and sympathize with their struggle against Russia. The Rusakov's would sooner consider themselves Estonians than Russians. It is in the early 1990's that Alexander Rusakov, now a single parent since the death of his wife, would have retired from his Russian military duty and decided to stay in Estonia with his family for good. Having three daughters and a son, Estonia provided a safe backdrop for raising a family.

A more non-traditional form of research was investigating the epidemic of smoking. The script calls for continual smoking by Manya. I am not a smoker. In fact I 
am disgusted with smoking; therefore, having to do it on stage became a huge obstacle for me.

For the first three weeks of rehearsal I somehow got away with not using cigarettes as props. It was not until the end of the third week that the director of Kolonists, Phillip Beck, told me I needed to merge Manya's smoking and drinking habits with the character work I had done. I was secretly mortified. Since I have never been a smoker, I did not want Manya to look like she was faking smoking. So, I began watching everyone who smoked. I counted the seconds between inhales, ashing, and finishing an entire cigarette. I studied the different ways people held their cigarettes: between their index and middle finger, between their thumb and index finger, if they cup their hand around their cigarette. I chose to hold my cigarette the typical way, between the index and middle fingers. I also learned that the time it took to smoke a cigarette depended on the types and duration of the drags taken from each cigarette.

Manya's character habitually needs cigarettes as a method of relaxation and escape from the realities of her life. For example, she resorts to smoking after having an unanticipated conversation with Yakov, the dacha caretaker, after discussing her late father. In order to spare herself the pain of such memories, Manya recovers by smoking. 


\section{DIRECTOR'S APPROACH}

\section{I don't want any of that Stanislavsky shit from you!- Charles Laughton}

Director Phillip Beck bases his directing on the Stanislavsky System. He believes having, knowing, and working your objective in each scene is the key to the success of acting. I do not work this way. I believe objective work alone flattens and simplifies the reality of the scene. It seemed as though Beck was overly concerned that each actor know their acceptable objective and portray that. For some, this may be the key to unlocking the mystery of their characters, for me it is merely a trap that gives a static portrayal of reality.

While I do believe "life onstage, as well as off it, consists of an uninterrupted series of objectives and their attainment" it seems too contrived to create an objective in order to inspire action (Stanislavski 51). In reality I am typically subconsciously aware of my objectives, and my actions tend to aspire from less prescribed methods. Instead, I strive to allow the action of a scene to arise organically first from understanding my character's beliefs, her relationships with other characters, what the scene is about, and how it progresses the story of the character and the play. Nonetheless, I am not one to force my disbelief of the Stanislavsky System onto others. Instead I take from it what I need and leave the rest behind.

Yet, what I admire about Phil Beck is that he does not force the actor to step aside from the role as Stanislavsky suggests and create a character incorporating predetermined physicalities, vocal qualities, actions, and intentions. He encourages a 
naturalistic type of acting in order to produce an exact "slice of life" onstage and seems engaged to the belief that an actor should exist within the realm of their own reality, allowing the character to inform the actor of their direction, but not rule and overtake the actor. Thus, the acting seems more truthful as to the realities of actual life. He accepts subtle shifts and dynamics within the role, and frowns upon outrageous imitations that divert the truthfulness of the representation of life existing onstage.

Beck's ability to let me develop my character without much dictatorial direction from him aided my creation of Manya. He allowed me to create Manya with very little input, other than stage directions. This encouraged me to give up some of my personal habits without having them acknowledged and becoming embarrassed. His silent support allowed me to be me, without criticism or speculation; the comfort level of each rehearsal permitted risk taking without worrying about failure or disappointment. 


\section{CHARACTER}

Preparing for the role of Manya began at the first reading of the play, before the audition process. The initial read is the only time when I can distance myself as actor from a role and take in a story for what it is without having to think about how I would say certain lines, or make certain choices. This is the most important part of the rehearsal process for me. I can allow my imagination to soar and clearly understand the playwright's story.

Upon reading the play I immediately realized there was something wrong with Manya. She sits in a chair smoking, quietly ignoring the string of questions her sister Sveta barks at her. If she has to speak she does so limiting her words to as few as possible to satiate the person questioning her. Her withdrawn behavior pulls the audience into her world in order to investigate her pain and suffering. She guardedly lives in a world she seems constantly threatened and annoyed by, which allows an empathetic onlooker to become consumed with her inner secrets.

Manya is merely existing in life. It is as if she were already dead. She is depressed, mainly by the death of Grisha, possibly suicidal. Manya, who does not believe in God, may be too stubborn to allow herself to actually succumb to her thoughts, therefore never allowing suicide to be a way out for her; she would rather suffer through life. In this suffering she finds her own unique solace and peace. She cannot let go of the suffering for Grisha or she may allow herself to forget him.

Manya's strange relationship with Vassily also serves as a reason for her reserved behavior. There are so many secrets between themselves; she is terrified that 
one may be revealed. When they were teenager they walked in on Manya's mother Anna and Vassily's father Sergei secretly making love to one another. There was also a line in the original script, "You're no longer a thirteen year old virgin" which was later cut, makes me believe Manya and Vassily may have been kissing cousins early in their adolescents. The tension between these two characters is appropriately evident, as Manya shamefully remembers her encounters with Vassily.

The loss of Grisha continues to be Manya's biggest emotional crisis. She is unable to function in daily life because she is wracked with tremendous guilt and sadness from losing him. Even though it has been fifteen years since his death, she is slipping deeper into depression. She does not want to leave her home. She finds it difficult to interact with people, even her family. Her mind is in a constant state of flux saddened with her loss and struggling equally to ignore those exact feelings.

Surprisingly, Manya's emotional characteristics are very similar to mine. I felt I understood Manya immediately. There are so many similarities which connect us. These ranged from being from a family of three daughters and one son, having a very pessimistic outlook on life, finding happiness in solitude, and having lost people we loved. Her confidence is not measured by the number of those who surround her, but rather by her own self worth and her ability to be her own best friend. We both put an invisible armor on to prevent ourselves from being hurt by others. We also both long for intellectual stimulus by those surrounding us, and neither of us believe we should needlessly sugar-coat our opinions when asked for them. As it seems there is so much of Manya in me naturally, in order to bring her fully to life I would have to allow myself to connect with whom I really am. 


\section{REHEARSAL}

While having had the privilege to play many character roles which have allowed me the luxury to create very vibrant and physically different people, the journey I took to bring Manya to life became a very different journey. Manya was unlike anything I had ever created. She was not a character that needed to be seen at all times, even though she was onstage ninety-nine percent of the play. She needed to blend into the backdrop of this play, just as she does in her reality. In other words, I did not need to fashion an exaggeration in order to create Manya, I needed to do the opposite.

My largest struggle with playing Manya was the idea of doing nothing. Typically I approach a role by asking myself, what can I do? How is this character different from the others I have played? How can I make it even more different, so people will see how creative I am? Through the courage I have gained these past three years, I felt I no longer needed to prove anything. I felt I was up for the challenge of attempting a new kind of acting, one that allowed a character to find itself within me rather than forcing it to develop.

I have always worked from the outside, creating characters based on my inventiveness. I will develop a funny walk or strange voice and make the character a ridiculous version of truth, almost a cartoon. I never knew you could create a character any other way. I am a product of scholarly training that has stressed the importance of creation: using your imagination to devise a character through the compilation of mimicking people who are the most unordinary in society. The end result is an unbelievable caricature that was more ridiculous than real. What I did not understand 
was that one must allow one's feelings and experiences to speak for themselves. You need not push them to another level making your experiences real and emotions false. "The actor does not need to 'become' the character...there is no character. There are only lines upon a page....when he or she says them...the audience sees an illusion of a character upon the stage. To create this illusion the actor has to undergo nothing whatever" (Mamet 9). My challenge then falls in believing in the given circumstances and resisting the habitual urge to do more.

In order to let go of my habit of "doing," I must change my definition of acting from "portraying" a person to "being" a person. For me an exceptional actor is one who acquires the unexplainable existence of talent, confidence, and common sense. One who brings a character forth to represent life to recreate a story that cannot be told by words alone but by images, conversation and life. No matter what that story is one must invest in one's own history in order to give depth of honesty to a character. All characters stem from the past of their performers mind; images, sounds, and emotions that they have lived. Where I have suffered, they have suffered. Where I have laughed, they have laughed. Where I have loved and lost, so shall the lives of those created onstage loved and lost. Acting is solely about allowing life to be recreated through ones own experiences of past and imagination. So why do I try so hard to create something that I am not?

I first recognized this habit when auditioning. Walking into the space, prepared to prove I could act, I instantly turned into a character, increased my energy level, and performed at a heightened level. Feeling positive I gave a stellar audition, I left the room, not understanding until later that I gave too much. I overpowered the auditioners 
with a vivid, imaginative caricature. Professor Theresa M. Davis pointed out to me that I do not need to push so hard when acting. I did not need to "become" someone else, but rather allow the text of the character to rise out of who I am. She even likened me to the movie Jerry McGuire, and said, "You have us from hello." Meaning when I walk into an audition or onto the stage, I do not need to become someone I think they want to see. I am interesting enough all by myself. I have been working diligently to recognize this aspect of myself and acknowledge that my individual essence is more dynamic and interesting, and allow it to work for me rather than trying to overpower and compensate for it in order to feel like I'm "working."

Instead of intensely creating Manya physically and vocally, I relaxed and made no physical and vocal choices. Rather, I let this character share my own voice. I thought about Manya's past, family, relationships, her likes and dislikes, and related all of them to mine. I created a historical journey of her life in my head and compared the similarities and differences with mine, replacing necessary elements in order for both of our pasts to converge and become one. As an actor, I do not think it is possible to create a character by changing yourself. You cannot change yourself, but rather you can allow yourself to be the vehicle to portray you in different imaginary circumstances. Using the Stanislavsky's Magic If, I ask myself, if I were Russian born in 1961 to a military family, I had seen my mother and uncle having intercourse, I found true love at twenty and suffered unspeakable loss at twenty-one, what would I be like?

The genius of good acting then becomes more of an art of peeling back ones own layers of denial, self consciousness and experiences, and finding the appropriate choices in ones own history to plug into that of the character's history. I have seen 
families torn apart by adultery; I have found my true love; and I too have suffered the unexpected and horrific losses of loved ones.

Working with others in a semi-professional environment, such as in the academic theatre, always seems to bring difficulties to the surface. When I began the rehearsal process for Kolonists, I went in prepared with preconceived notions of who Manya is. I allowed myself to imagine the journey of the play, the relationships between my character and others, and how the story should be portrayed on the stage. My intentions with theatre are to always behave professionally, be prepared, and employ common sense. Many of the other actors, however, seemed to find this specific given circumstance work unnecessary.

Many in the cast of Kolonists seemed to lack the abilities to think on their feet, take direction, and problem solve. Instead of thinking through simple blocking, text, and given circumstance problems they spent precious rehearsal time questioning the obvious. Many actors were late or never showed up to rehearsals. The effect of working off of a Stage Manager prompting lines in rehearsals severely a ffected the final development of character and exploration of life on stage.

Rather than focusing on the lack of professionalism that ran rampant through the rehearsal process, I chose to return my focus to the needs of Manya. The relationships developed between my character and others became solely based on my ability to "pretend" I was receiving the necessary response from other actors. While the script was determinate on the creation and success of an ensemble both onstage and off, the appearance of ensemble was only created on stage. 


\section{EMOTIONAL JOURNEY}

\section{"[The audience comes] to the theatre to see a play, not to see the work}

done on the play." - Robert Edmond Jones

The most rewarding and most challenging aspect of playing Manya was the character's psychological collapse in the final scene of the play when she finally succumbs to her deep bereavement of the death of her fiancé Grisha. The breakdown begins after Manya tells Vassily he is nothing more than a fat, balding coward. Vassily returns by striking where Manya is weakest:

VASSILY. You're holding in a lot of repressed anger there. Manya. Not surprising for a woman who hasn't been fucked in fifteen years. So what went wrong, Manya? Couldn't daddy swing an exemption for Gregori? I can't believe that. He was happy enough to get Andrei off the hook. Your father got you everything you ever wanted. Answered your every prayer. Jesus, the man was a god! Can't believe he let little Grisha get his fucking head blown off. Not his darling Manya's little Grisha. I don't know, you think you know someone and then they go and do something as thoughtless as that. (Scene 3)

Manya is emotionally deconstructed by Vassily's comments. Vassily uses all three men Manya has loved in her life: Grisha - her father, and Andrei - to ruin her sense of strength. Vassily begins by pointing out Manya's apparent lack of intimate relationship which is a direct dig to her vulnerability for Grisha. He then denounces her father by suggesting he is guilty for Grisha's death by not doing all he could to keep him out of war and compare that to his ability to keep Andrei safe at home. Vassily then throws the largest blow by telling Manya how Grisha died, "getting his fucking head blown off." This is where Manya breaks. She had been protected from knowing the nature of Grisha's 
death by her family and now becomes flooded with the grotesque images of her faceless Grisha. This comment propels Manya into a state of complete despair. The barriers she has placed around her fragile psyche begin to crumble and she begins to outwardly grieve for the loss of Grisha.

After fighting against her desire to outright weep in front of Vassily, she controls herself and is able to suppress her feelings once again. Yet, it is only a few moments later when Vassily has exited and she is left alone with Yakov that her wall finally crumbles quite unexpectedly:

YAKOV. When a tradesman sleeps, his trade sleeps too. When a farmer sleeps, his crops still grow. My father used to tell us that. Vassily Rusakov would do well to heed it. Don't you think so, Maria?...Borsch was good. Excellent.

MANYA. I miss him.

YAKOV. Huh?

MANYA. I miss him. I miss him. I want him back. What was inside, I want it back.

YAKOV. My mother cries like that. Hours on end. Then she sleeps. (Scene 3)

As Yakov attempts to comfort the fragile Manya, she releases her pain without restraint only on her second "I miss him" line. At this point the audience is already encapsulated with Manya's struggle, but at the unexpected moment of her full release of agony, it is only then the audience wholly realizes her suffering and empathizes as they weep openly along with her.

The outpouring of emotions from Manya in the final scene of the play was solely reliant on my complete mental entanglement with the character. The challenge for me laid in the truthful portrayal of an emotional outburst of weeping. 
Nothing in the world is less interesting than an actor on the stage involved in his or her own emotions...the very act of striving to create an emotional state in oneself takes one out of the play. It is the ultimate self-consciousness in the service of an ideal, it is no less boring for that. Mamet 10

In order for the scene to be believable I knew I wo uld have to allow myself to be affected by the loss of Grisha. Thus, in order to build the suspense and journey of the character the through-line of given circumstances had to be linked together and reexamined before each performance.

By no means was my intention to play the end of the play, but I had to envision the grotesque images of Grisha having his head blown off before even stepping foot onstage in order to correctly grasp Manya's depressive state of mind. This image not only gave me impetus for the emotional state Manya seemed to dwell in, but also built the quality of her character within me. The images I conjured up of Grisha's death made me physically nauseas which thus propelled a sort of nervous and uneasy disposition onstage. I was able to more fully understand her despair of loss by the direct affect of those I have lost.

Rather than relying on the seemingly disembodied emotional recall exercises of Stanislavsky, I was allowed to reach an emotional level through each performance by simply believing that those things were actually happening to me. I have never believed in the principles of emotional recall exercises. "'Emotional memory,' 'sense memory,' and the tenets of the method back to and including Stanislavsky's trilogy are a lot of hogwash, it is as useless as teaching pilots to flap their arms while in the cockpit in 
order to increase the lift of the plane" (Mamet 12). I have often asked myself, how can I produce an emotion that is likened to an event that I have no emotional perception of? I have no emotional recall memory that would compare with the death of my fiancé in war. Therefore I would be doing the part of Manya a disservice if I were to insert a past, and almost certainly less severe emotional response, for that of the emotional response of Grisha's death. While my personal past emotional experiences have shown me how I behave at the death of certain people, it is by no means the key to providing all of the emotions wrapped into the life and experiences of Manya.

Yet, I needed to conjure up an image of Grisha in my head in order to succeed as Manya. Christine Edwards says, "Stanislavsky makes it very clear that while the actor's personal experience may be used as a springboard for arousing the emotions required in the part, the emotions sought should be those demanded by the role, in other words, those of the character, and therefore not necessarily those which the actor would experience at that moment" (Vandenbrouke 86). While I have not lost a fiancé to the destruction of war, Manya and I do share the history of being engaged and in love. I then allow myself to envision my fiancé in replacement of Grisha and imagine I was to lose him. The reality of my emotions for that "pretend" death and the loss of the hopes and dreams we shared left me believing my own complete devastation. By allowing myself to trust the pain of my loss, I can then give Manya my very real response to the loss of my fiancé.

Not only are the emotions conjured up for the sake of Manya's journey, but also for the sake of allowing the story to be truthful. The moments of weeping onstage then become the direct effect of conjuring up and following the mapped out plan of my 
emotional journey throughout the play and believing that what is happening to the character is actually happening to me.

In A Practical Handbook for the Actor, the authors examine the pitfalls and successes of emotional incorporation from actor to character. By accepting that "every action will give rise to an emotional condition; you won't have to work for it. Once you accept that there is no such thing as a correct emotion for a given scene, you will have divested yourself of the burden of becoming emotional” (Bruder 71). Finally understanding that I do not need to consistently recreate the same emotional response in the final scene, but rather simply follow the given circumstances throughout the play enables me to truly have the emotions necessary as the capstone of Manya's journey.

To imagine that this woman has held these emotions in for nearly fifteen years proved to me that the initial release of the emotions would be fierce, uncontrolled and without abandon. Yet, in order to allow the audience a greater understanding and experience of Manya's pain, I knew I could not give them all of the emotions at once. In fact, I realize that if the actor fully indulges in the emotional experience of the moment, the audience will be more moved to watch them experience the emotion rather than having the emotions themselves. "All you need is the key for [the audience] to feel; it does not have to be done for them...they need only be reminded of their own true feeling about the situation" (Lewis 89). In order to get the audience to weep for Manya I could not show them the plethora and range my emotions, instead I must portray the fight suppressing the emotions and in the portrayal of that struggle the audience will shed their own tears. 
Previously I believed I was an exceptionally skilled actor who could prove to her audiences she could go to great emotional lengths to show how truly talented she is; however, having not succeeded at moving my audiences other than showing them my range, proving, "the great actor, capable of bringing herself to tears, may extort [the audiences] admiration for her 'accomplishment,' but she will never leave us stronger, she has made us pay a price, and made us pretend we like it, but we leave the theatre moved only by our capacity to be moved" (Mamet 14). In order to allow the audience to feel without overwhelming them with my skill to cry on command, I had to use the embarrassment I felt overwhelmed with from having a breakdown in front of the other characters and fight against showing the emotions bubbling up under my surface. Through this struggle, the audience then experiences the culmination of Manya's emotions, rather than unabashedly indulging in my own emotional greatness. 


\section{BREAKING HABITS}

I heard somewhere that you can only consider yourself a true actor if you are either performing in theatre or are furthering your acting training. Having spent the past three years doing the latter, I still found it difficult to refer to myself as an "Actor," mostly due to the dissatisfaction I felt regarding my inability to allow myself to delve into creating honest characters. Somehow over the duration of my acting career I have subconsciously avoided the honest connection between myself and the role which I am to develop.

I have previously thought of being an actress as someone who "acts" like other people. I never thought of acting as just being the person you are naturally. The definition of "act" is a form of doing, not allowing. In order to create a character I developed a different voice, appearance, and overall presence. Since coming to graduate school I have been re-trained to avoid creating a character by going to the furthest extremes of her given circumstances, but rather allow her given circumstances to live within me without forcing an apparent difference between myself and the character. In order to fully allow a character to live within myself I would need to find a new way of acting.

Novelist, playwright, and theorist Emile Zola says that the connection between the performer and a "real" character is not possible, as performers merely imitate their own conceptions of life on-stage. It is fact that actors will never actually become their characters, they can, however, use themselves as an outlet for the character. 
The portrayal of Manya lends itself as the prime example of my approach to acting. Having to play Manya was not necessarily going to be a challenge textually or physically, but rather the challenge would lie in having to let go of some of my beliefs and habits in order to allow Manya to have a more "real" presence onstage. I would need to work from within to understand my process and correct some misunderstandings regarding my definition of acting and what looks good onstage.

By delving into my technique's flaws and habits I can begin to piece together a more honest character. In the past, I believed that acting was the concoction of the creation of a character. In order to be successful onstage, the actor must step aside and allow the character into their bodies. The primary method I have studied in both undergraduate and graduate school, that of Stanislavsky, supports the effectiveness of creating a character through the layering of such imaginative physicalities and vocal variations. Yet, what I have not realized, until now, is that character creation can also be successful by peeling back your own layers and revealing a side of yourself, the actor.

Another habit that I discovered during the development of Manya was the need to save the show. What I mean is, when another actor is not giving a performance that is up to par, I have an overwhelming impulse to step up my energy in order to draw attention from the other actor's shortcomings thus providing the audience with their money's worth. Over the years this has developed into quite a habit. Specifically, I recall when I played Germaine in Picasso at Lapin Agile. There were many young, inexperienced actors in the show. I was mortified that we would not get good reception from audiences, so I pushed myself and my character to be larger than life. My energy 
was insurmountable as I intended my presence to be larger than life. I subconsciously wanted to steal each scene I was in, in order to draw attention away from the other actors. The performance thus became all about me; it was not centered around the creation of an ensemble, where trust is a key dynamic.

In Kolonists, I was very aware of this habit, and vowed to myself that I would overcome any urge to save the show. There were many times in rehearsal and performance the desire to pull attention from another actor was great. Nonetheless I vowed I would concentrate on my character and allow those who may be less experienced to learn by their mistakes and inexperience. I had to allow myself to understand that their failure was part of their acting training, just as it has been in mine. During rehearsals I found that undoing the habit of "stealing the show" allowed myself to be more present for the existing events taking place. It allowed me to open up to other actors and truly listen to them in each moment. I was no longer concerned with the appearance of the show, but rather the relationships developing between myself and others.

One's voice is truly the most powerful tool they possess as a performance artist. It has become a gateway for examining the link and voyage between actor and character. I notice that when I build a wall between myself and the character for various reasons (i.e. not wanting to play the role, or not being emotional prepared to go "there") I begin by segregating myself vocally and unnaturally from the text. I do not know for what reason, but when I begin to say lines that do not come directly from my thoughts, I suddenly do not know how to say them in a "real" voice. I concentrate on diction, and 
sound, rather than my natural vocal vulnerability. After being told by Phillip Beck that my voice did not sound natural I began to make a conscious effort to correct the problem. I noticed in rehearsals that I would begin to "act" as Manya, rather than just be Manya. During these times my voice became very controlled and qualitative. I had begun forcing my voice in order to show a certain part of Manya's inner life to the audience. The portrayal of this inner life stole the reality of Manya's existence. I began "acting" the way I perceived she should behave, and cutting off all connection of providing myself as an outlet to Manya's story.

When I began feeling the need to show the audience an emotion or felt myself controlling my voice, I took a deep breath, relaxed by pelvis and found my natural voice and continued speaking from there. I discovered tension in my pelvis cuts me off from all vulnerability. The direct correlation between tension in my core thus affected me vocally producing a controlled forced sound. When relaxed, and allowed my pelvic floor to drop, I instantly became vulnerable and was able to find my emotional connection to the circumstances taking place.

Maintaining my natural voice was difficult at first. I was extremely vulnerable while speaking with it. I felt completely open and attacked when spoken to. As rehearsals progressed, and I became more familiar with my natural sound I was able to overcome my fear of speaking so honestly.

When I overcame this fear to connect to Manya vocally and allow her voice to find itself within my real voice the role and life of the character naturally began using myself as a gateway to expression. I could not believe the power my vulnerability lent 
the role. The text no longer seemed estranged from my thoughts, but the words became mine. Thus the overall performance of the role became more real. 


\section{PERFORMANCE}

The performance of Manya was the culmination of my ability to let go of my past habits and beliefs of what acting should be. I knew I was taking a huge risk by allowing myself to be real and truthful onstage and only using my experiences to inform who Manya was going to be. Before opening night, I became overwhelmed with the feeling of guilt that I had done nothing to create a character; still I would not allow myself to impose my habits out of fear of failure. I took the stage knowing I had only to allow myself to exist within the parameters of Manya's given circumstances, which alone is enough. The audience would then piece together her journey and arrive at their own discoveries. There was no funny walk or voice, or preconceived notion about the effect I wanted to have over an audience. I just existed.

While existing onstage, my perception of the life around me became greatly increased. I believe this was the result of being so relaxed. I noticed many actors turning on emotion for the sake of speaking their lines and affecting the audience, yet, the result of this only portrayed them as opinion-less and fake. Many actors seemed to only be exploring their character's given circumstances while speaking their lines, and when not speaking withdrew from the scene and became un-invested in the story unfolding in front of them. Nevertheless, I find that it is these non-speaking moments that an actor truly gives life to their character. At this time you must connect and map out the journey of your character.

While some actors performed on automatic, there were moments that allowed me to fully embrace and live as Manya. The scene with Max (Andrei) was the first time I 
have ever felt truly at peace onstage. I never felt close to Max before this, but this moment of honesty, of allowing myself to feel Max's energy, Manya's brother's energy and to truly see him and not think of the audience, felt remarkable. This ease allowed me to connect with Andrei in every scene we were in together, and give life to all of our silent moments together.

Neil (Vassily), on the other hand, was very difficult to act with. I looked into his eyes and saw confusion and hesitation, not that of the characters, but that of the actors. I felt I could never allow myself to settle into the moments between Manya and Vassya, because I was technically concerned with Neil's line memorization and lack of ease onstage. I believe the audience read this as Manya's unease with Vassily therefore progressing her relationship between the characters, however I never felt I truly portrayed Manya's emotions, but rather that of an actress that was preparing herself the unexpected memorization blip, which did on more than one occasion.

Many actors never were off book. I find I am in the minority in the belief that it is the actor's job to be word perfect for performance, yet many actors in Kolonists were never word perfect, and in some performances actually made up lines, or consistently forgot the same ones even after being reminded time after time. These actors seemed to possess the ability to forgive themselves immediately after each mistake which then never prompted them to correct it. During many of the performances my concern then drifted from the life of my character to that of the actor problem solving and assisting actors who dropped lines.

There were also design difficulties to overcome during the final days of rehearsal and the journey through the run of the show as well. One rather ridiculous challenge 
became my image of what Manya looked like and that of the Costume Designer, Pavlo Bosyy. I have never cared what my character wears. I always find it exhilarating to have the added layer of costume propel the character deeper into reality, however I was truly devastated when I first put on Manya's clothes and wig for the very first time. Firstly, the costume looked nothing like the rendering. The rendering consisted of a t-shirt and bohemian style skirt with simple, classic sandals and sleek black bob-styled wig. I was excited to see the sketch of what others saw Manya as. As we got closer to the show's opening it was decided to have a costume parade. This was the first time I got put on my costumes and wig. I was mortified. The costume no longer looked like the renderings of a casual thirty-two year old, but rather that of a sixty year old living in 1940. What was originally supposed to be a t-shirt and bohemian skirt now turned into two outfits, one being a dowdy, floral print dress, adorned in yards of thick cotton lace trim, the sandals were far from dainty, closer to the representation of what Jesus may have worn, and the wig was a dead ringer for Cookie's hair from the Bozo Show, only dyed black. I stepped out in this ensemble to outright hilarity which then turned to silence as everyone slowly began to realize this was not a joke. I have never cried before over something that seemed so petty, but I could not resist the tears. I was not ashamed of the costume, in fact in any other play I would have loved to look so freakish, but Manya was not a freak. She became real to me. I did not want audiences to laugh at her appearance. I wanted her to blend into the background. I had worked so hard creating an emotionally vibrant and real character that was now being turned into a joke. So I cried, silently, and Phil Beck came to my rescue and forbade the wearing of the wig. For the show was not about looking dark, with black hair, the show was about a 
woman who was silently suffering. I wanted to audience to see that and not be distracted by a horrific wig. In the end, I decided to spray my hair dark brown, which looked remarkably natural and best of all, took nothing away from the creation of a real character. 


\section{EVALUATION \& CONCLUSION}

The success of my portrayal of Manya in Kolonists was solely dependent on the full submission of myself, my experiences, and my emotions. The role allowed me to begin breaking acting habits and think differently of what acting actually is. Through allowing myself to live onstage and letting go of my long imbedded habits and beliefs I finally am able to make people experience the life of Manya.

While I have always understood beauty is in the simplest of forms, I had never believed acting was also most profound and most affective when done simply and honestly. Though I have completed the role of Manya, I have certainly not completed my own journey. While I have found a new confidence in minimal acting, surely, I will continue to be type-cast as the boisterous character actress. Yet now I know that even the most extreme character must begin within the depths and history of the actor. The honesty found within an actor's experiences is the key to creating a full and rich creation for the stage not the imposition of outside elements alone.

Of course there are things I would do differently or further explore if I were to play Manya again. Namely, I would challenge myself to use my own connection with Manya to exist as the basis of creation and further explore the possibilities of the role, and the differences between myself and the character. I seemed to have understood her from the very beginning and became attached to my initial images of the play. The element of play as an actor, while somewhat explored, may have been further investigated in the rehearsal process. My own fears of failing to be real and true to myself and the character restrained me from making a choice that was too inventive, thus seeming 
phony. I was consumed with the trepidation that if I "tried" to create something I would remove the very truth of the character and again submit to my habits.

Despite the looming fear in each performance that I was not "doing" enough, I realized I had truly succeeded by the outpouring of feedback from professors, peers, and complete strangers. Both friends and strangers approached me weeping, some quite uncontrollably. I never expected I had the ability to move an audience as much as I did when portraying Manya. Endless numbers of people would approach me after the show, still grieving for Manya. I found myself comforting friends and strangers from the audience after each performance. At first I was baffled by the power of my performance as I felt I did nothing extraordinary, however, it was in the resistance of doing or creating something, that I truly found myself and allowed the audience to see Manya through who I am. "Because, remember it is the audience that goes to the theatre to exercise its emotion - not the actor, the audience" (Mamet 25).

In performance, the power of my own being proved to be far more complex, dynamic, and intriguing than any character I could possibly surmise. The leap of faith I took in believing that I was enough and to allow myself to inform the life of Manya led to a new breakthrough in what acting truly is - a journey of character through the exploration of self. 


\section{WORKS CITED}

Brandt, George W., ed. Modern Theories of Drama. Oxford: Clarendon Press, 1998.

Bruder, Melissa, Lee Michael Cohn, Madeleine Olnek, Nathaniel Pollack, Robert

Previto, and Scott Zigler. A Practical Handbook for the Actor. New York:

Random, 1986.

Dykes, Steven. Kolonists. Unpublished play, 2004.

Jones, Robert Edmond. The Dramatic Imagination. New York: Theatre Arts Books, 1941.

Lewis, Robert. Method - or Madness?. New York: Samuel French, 1958.

Mamet, David. True and False. New York: Pantheon, 1997.

Morris, Eric, and Joan Hotchkis. No Acting Please. Los Angeles: Ermor Enterprises, 1977.

Stanislavski, Constantin. Creating a Role. New York: Theatre Arts Books, 1961.

Vandenbroucke, Russell. The Theatre Quotation Book: A Treasury of Insights and Insults. New York: Limelight Editions, 2001. 